(6)

OPEN ACCESS

\title{
Recurrent gastric metal bezoar: a rare cause of gastric outlet obstruction
}

\author{
Elias Chahine, Lionel El Khoury, Ramez Baghdady, Elie Chouillard
}

Digestive and Minimally Invasive Surgery, Centre Hospitalier Intercommunal de Poissy/SaintGermain-en-Laye, Poissy, France

\section{Correspondence to}

Dr Elias Chahine,

dr_elias_chahine@hotmail.com

Accepted 15 September 2017

\section{SUMMARY}

A 52-year-old male patient with psychiatric medical history who presented to the emergency department five times during a period of 5 years due to gastric outlet obstruction manifested mainly by abdominal pain, vomiting and haematemesis after intentionally ingesting metals and which necessitate several surgical interventions. Lately, he presented with generalised peritonitis due to gastric perforation from metal bezoars. Chronic abdominal symptoms in patient having a psychiatric disorder can be due to foreign body ingestion. Treatment is often surgical and the whole digestive tract should be explored to avoid retained bezoars.

\section{BACKGROUND}

Bezoars are accumulation of foreign bodies formed of partially digested or non-digested foreign material in the gastrointestinal (GI) tract; most commonly found in the stomach but can be seen elsewhere in the digestive tube. ${ }^{1}$

Several types of bezoars are named according to the material from which they are composed.

Bezoar could be food boluses composed of loose aggregate of food items, lactobezoar formed by

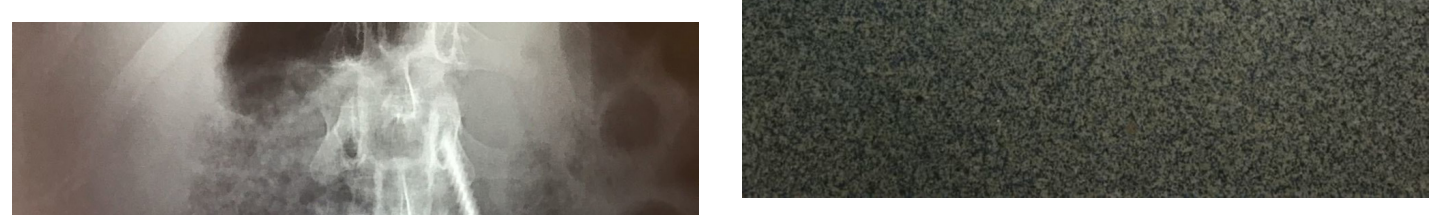

Figure 2 Metal items retrieved from patient's stomach.

inspissated milk usually seen in infants, pharmacobezoar formed by medical tablets and masses of drugs, phytobezoars composed of indigestible plant material, diospyrobezoar a type of phytobezoar formed by persimmons, trichobezoar formed by ingestion of hair and the least frequent being metal bezoar, ${ }^{2}$ usually seen in patients having psychiatric disorders. Few cases have been reported in the literature. $^{34}$

We present a case of a psychiatric man who was operated several times due to relapsing massive metal bezoars despite psychiatric treatment.

\section{CASE PRESENTATION}

A 52-year-old male patient with chronic psychosis and under specific psychotic treatment, presented in May 2012 with signs and symptoms of gastric

Figure 1 Radiograph showing metal bezoar. 


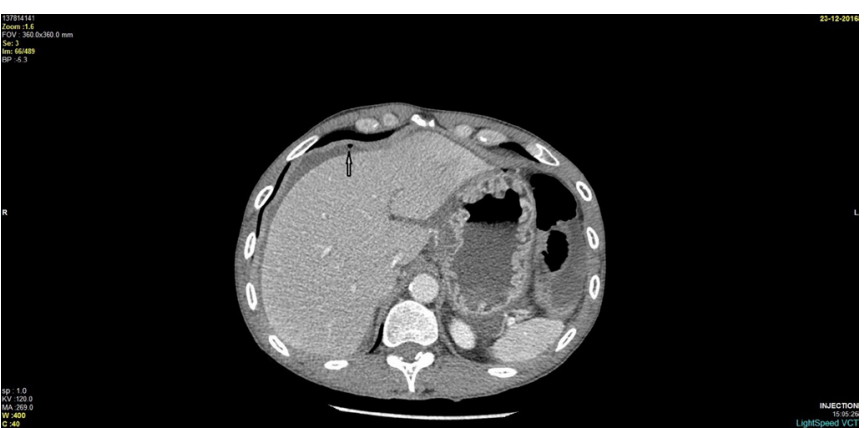

Figure 3 CT scan of abdomen showing pneumoperitoneum (arrow) and free intra-abdominal fluid.

outlet obstruction due to the ingestion of metal bezoar, which was removed endoscopically. Eight months later, he was readmitted and operated because of failing endoscopic total removal of the different metals ingested. These bezoars were nails, knifes, screws, nuts, spoon handles, screwdriver head, washer, pebbles, coins and iron wire (figures 1 and 2).

Between 2013 and 2016, he was readmitted and operated two times in another institution for gastric metal bezoars after failed endoscopic removal in each intervention. The patient had laparotomy and metal bezoars were removed via gastrotomy.

Lately in December 2016, he was presented to the emergency department with fever and nausea; on physical examination, his vital signs were within normal limits except a moderate sinus tachycardia $110 / \mathrm{min}$ and $38^{\circ} \mathrm{C}$. He was pale and dehydrated.

Abdominal examination noted guarding throughout the abdomen, maximally in the epigastrium.

A mobile mass was palpable in the left upper quadrant and epigastrium.

He was admitted with provisional diagnosis of generalised peritonitis due to gastric perforation.

\section{INVESTIGATIONS}

Blood tests revealed that the patient was septic with a haemoglobin level of $13 \mathrm{~g} / \mathrm{dL}$; peripheral white cell count was $20.110^{\wedge}$ 9/L with neutrophils $85 \%$. C-reactive protein was $200 \mathrm{mg} / \mathrm{L}$, urea $15 \mathrm{mmol} / \mathrm{L}$ and normal creatinine.

Abdominal CT scan showed a foreign body mass in the gastric region and small bowels associated with pneumoperitoneum and free intra-abdominal fluid (figures 3-5)

\section{DIFFERENTIAL DIAGNOSIS}

Differential diagnosis includes ulcer perforation, left transverse colon tumour.

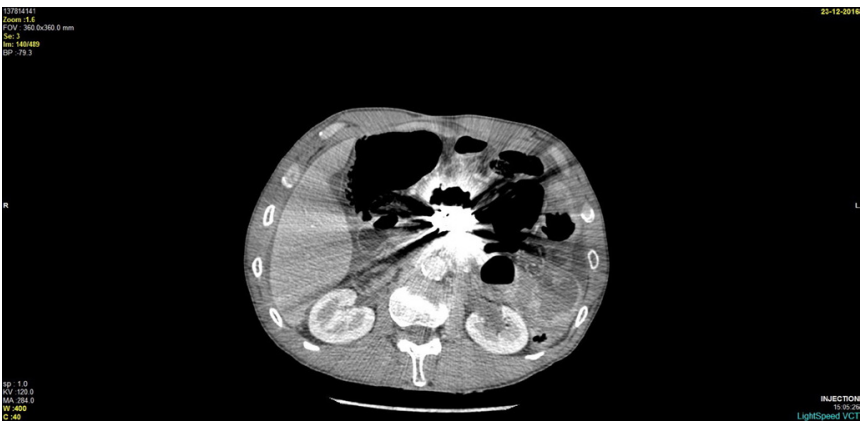

Figure 4 CT scan of abdomen showing intragastric metal and free intra-abdominal fluid.

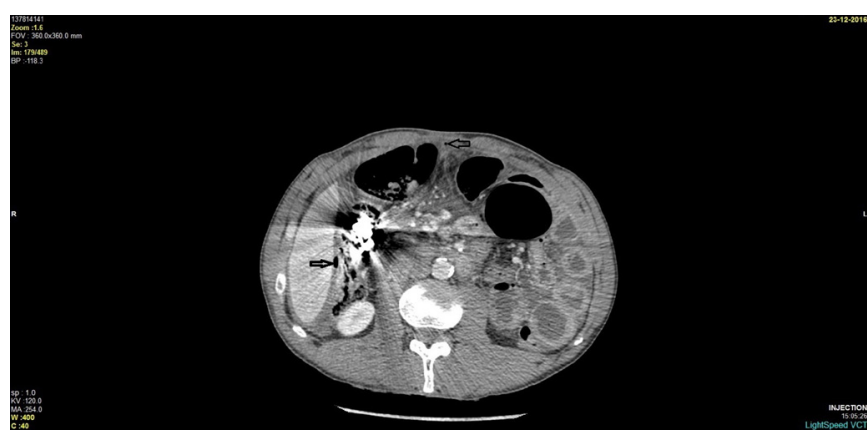

Figure 5 CT scan of abdomen showing prepyloric metal with pneumoperitoneum (arrows) and free intra-abdominal fluid.

\section{TREATMENT}

The patient ultimately underwent an open laparotomy, bezoars were removed via gastrotomy and many enterotomies since the radiologic perioperative findings help us to localise all the materials and to check for their total removal to prevent recurrence (figures 6 and 7).

\section{OUTCOME AND FOLLOW-UP}

To note that those different medical and surgical consultations were despite the theoretically psychiatric medications and follow-up.

The postoperative course was uneventful and the patient was discharged on postoperative day 15 with a referral to behavioural and mental health providers.

\section{DISCUSSION}

Bezoars are uncommon findings in the GI tract; they are composed of a wide variety of material depending on the type of the ingestion. By order of frequency, phytobezoar is the most common, followed by trichobezoar, drug bezoar and lactobezoar. Metal bezoar are the least common and very few cases are described in the literature. ${ }^{5}$ Bezoars are usually intentionally

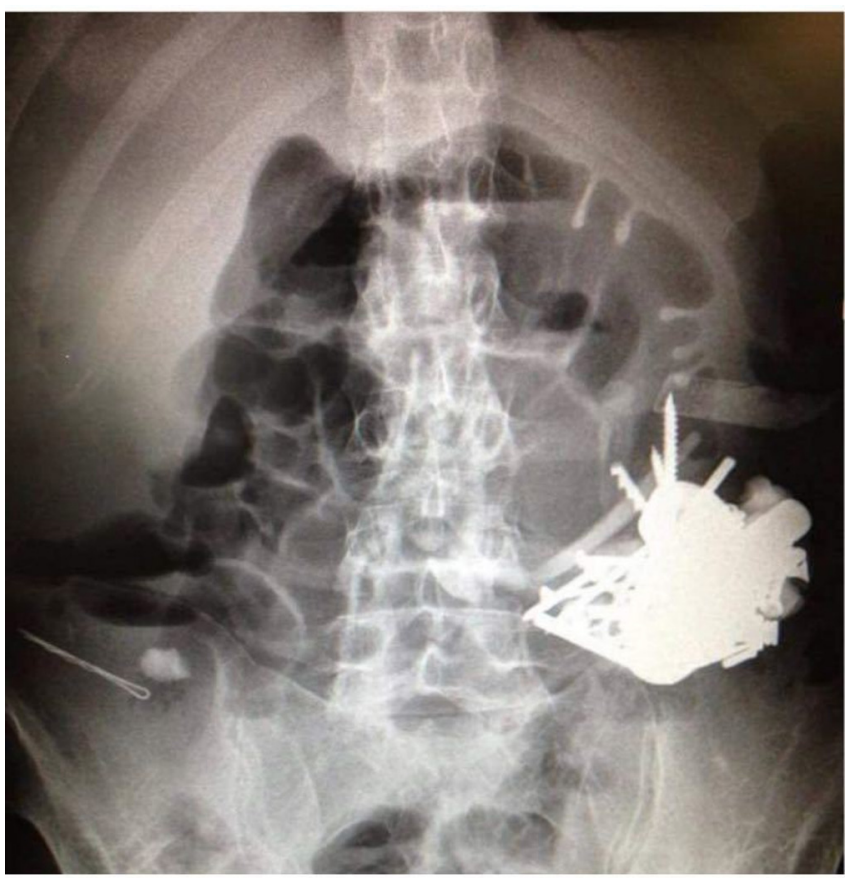

Figure 6 Radiograph showing metal bezoar. 


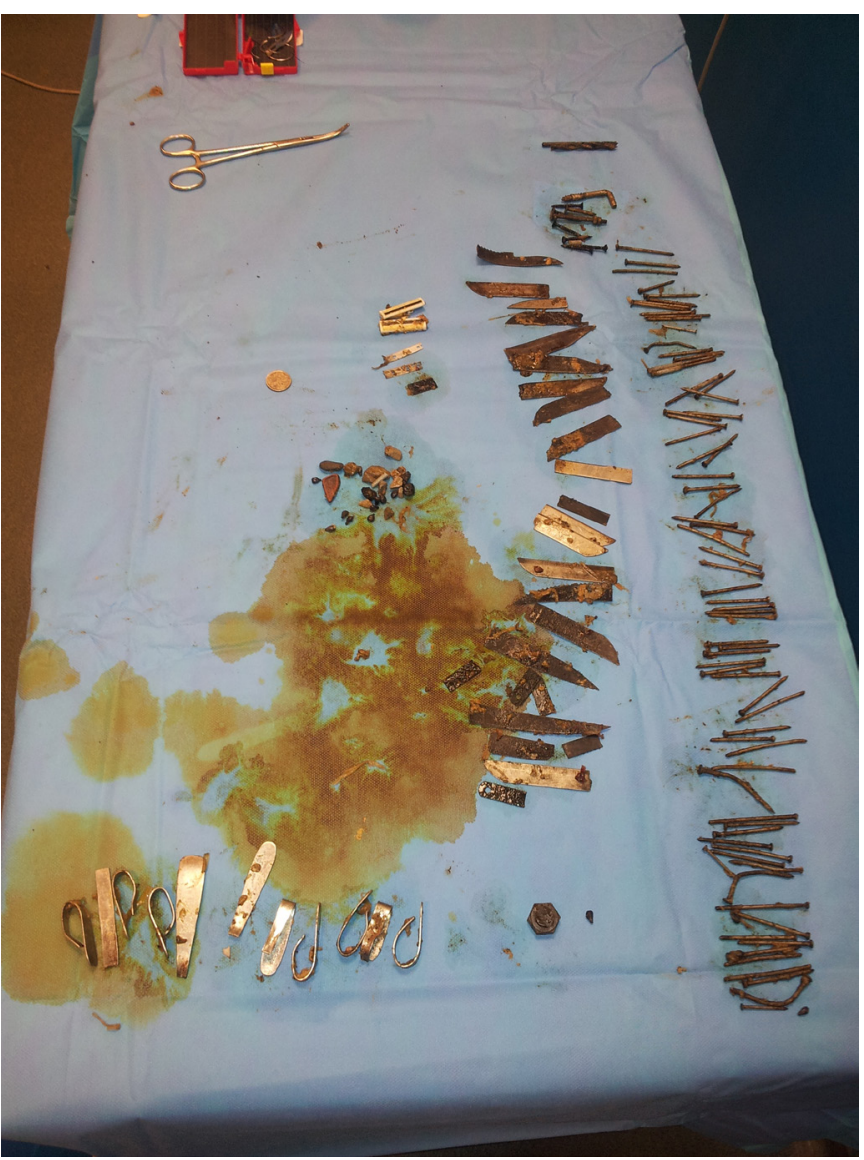

Figure 7 Metal items retrieved from patient's stomach.

ingested, thus they occur in normal stomachs and are caused by foreign bodies that cannot bypass the pylorus.

After reviewing the literature, metal bezoar was reported seven times. The first report was in 1956 by Salb ${ }^{6}$ and the second by Kaplan $e \mathrm{al}^{4}$ in 2005; later several cases were reported. ${ }^{12578}$ None of the reported case was recurrent, complicated or massive.

However, other bezoars could occur in 'abnormal' stomach, for instance, in cases of decreased gastric motility (eg, diabetes mellitus, previous vagotomy, drugs), previous gastrectomy (Billroth 2, gastric bypass), hypochlorydria, gastric stasis, loss of pyloric function and hypothyroidism. ${ }^{7}$ Clinical manifestations vary widely depending on the location of the bezoar that could be anywhere in, the digestive tract and can go from asymptomatic, non-specific symptoms to more serious intestinal obstruction, GI bleeding, perforation and peritonitis. ${ }^{9}$ Metal bezoar can be seen on plain radiographs unless they are radiolucent but CT scan is usually necessary and help identifying localisation and possible complications due to these foreign bodies. ${ }^{157}$ Gastroscopy confirms the diagnosis, defines the type of the bezoar and could treat the bezoar by its removal if they were small and technically feasible. ${ }^{10}$ Although different treatments have been suggested to treat phyto-tricho-bezoars such as coca-cola, papaine saline and other chemical substances for dissolution, ${ }^{11}$ endoscopic extraction, surgical treatment is usually necessary for metal bezoars. ${ }^{8}$

Metal bezoars could be a rare cause of abdominal concern. They are generally ingested accidentally in adults, usually in infants, elderly, psychotic patients and prisoners. The patient could be asymptomatic. Surgical exploration and extraction is the treatment of choice and thorough exploration of the whole digestive tract is necessary to avoid retained materials. Psychiatric follow-up is mandatory to prevent recurrence that has been reported to be $14 \%$ in the literature. ${ }^{12}$

\section{Learning points}

- Chronic abdominal symptoms in patients having mental disorders can be due to foreign body ingestion.

- Surgical exploration and extraction is the treatment of choice.

- Psychiatric close follow-up is mandatory to prevent recurrence.

Contributors EC is the primary author and performed writing and editing. EC is the senior author involved in writing, editing and supervising the manuscript. LEK helped in editing and case discussion. RB helped in editing and literature search.

Competing interests None declared.

Patient consent Guardian consent obtained.

Provenance and peer review Not commissioned; externally peer reviewed.

Open Access This is an Open Access article distributed in accordance with the Creative Commons Attribution Non Commercial (CC BY-NC 4.0) license, which permits others to distribute, remix, adapt, build upon this work non-commercially, and license their derivative works on different terms, provided the original work is properly cited and the use is non-commercial. See: http://creativecommons.org/ licenses/by-nc/4.0/

(c) BMJ Publishing Group Ltd (unless otherwise stated in the text of the article) 2017. All rights reserved. No commercial use is permitted unless otherwise expressly granted.

\section{REFERENCES}

1 Kumar GS, Amar V, Ramesh B, et al. Bizarre metal bezoar: a case report. Indian J Surg 2013;75:356-8

2 Márquez-Rojas J, Roldán-Baños S, López-Guerra D, et al. Bezoar after ingestion of metallic foreign bodies. Cir Cir 2011;79:464-7.

3 Ersoy YE, Ayan F, Ersan Y, et al. Gastro-intestinal bezoars: thirty-five years experience. Acta Chir Belg 2009;109:198-203.

4 Kaplan R, Celebi F, Güzey D, et al. Medical image. Metal bezoar. N Z Med J 2005:118:U1588

5 Siddiqui ZR. Metal bezoars causing upper gastrointestinal obstruction in a schizophrenic. APSP J Case Rep 2011;2:14.

6 Salb RL. Metallic bezoar. Med Radiogr Photogr 1956;32:32-3.

7 Prieto-Aldape MR, Almaguer-García Fl, Figueroa-Jiménez SE, et al. Relapsing massive metal bezoar: a case report. J Med Case Rep 2009;3:56.

8 Yasin MA, Malik GN, Malik SA, et al. Metal in stomach: a rare cause of gastric bezoar. BMJ Case Rep 2009:2009.

9 Andrus CH, Ponsky JL. Bezoars: classification, pathophysiology, and treatment. Am J Gastroenterol 1988:83:476-8.

10 Kuroki Y, Otagiri S, Sakamoto T, et al. Case report of trichobezoar causing gastric perforation. Digestive Endoscopy 2000;12:181-5.

11 Ladas SD, Triantafyllou K, Tzathas C, et al. Gastric phytobezoars may be treated by nasogastric Coca-Cola lavage. Eur J Gastroenterol Hepatol 2002;14:801-3.

12 Robles R, Parrilla P, Escamilla C, et al. Gastrointestinal bezoars. Br J Surg 1994:81:1000-1. 
Copyright 2017 BMJ Publishing Group. All rights reserved. For permission to reuse any of this content visit http://group.bmj.com/group/rights-licensing/permissions.

BMJ Case Report Fellows may re-use this article for personal use and teaching without any further permission.

Become a Fellow of BMJ Case Reports today and you can:

- Submit as many cases as you like

- Enjoy fast sympathetic peer review and rapid publication of accepted articles

Access all the published articles

- Re-use any of the published material for personal use and teaching without further permission

For information on Institutional Fellowships contact consortiasales@bmjgroup.com

Visit casereports.bmj.com for more articles like this and to become a Fellow 